\title{
The Relationship between Critical Thinking and Translation Ability of EFL Undergraduate Students
}

\author{
Wafa Ismail Saud ${ }^{1}$ \\ ${ }^{1}$ Department of English, Faculty of Languages and Translation, King Khalid University, Abha, Saudi \\ Arabia \\ Correspondence: Wafa Ismail Saud, King Khalid University, Abha, Saudi Arabia. \\ Email: wesaud@kku.edu.sa
}

Doi: 10.23918/ijsses.v7i3p19

\begin{abstract}
The present study was an attempt to investigate the critical thinking skills of EFL undergraduate students as well as to examine the relationship between their critical thinking skills and translation performance. The participants were 72 undergraduates majoring in English at King Khalid University, Abha, Saudi Arabia. Data were collected by means of Cornell Critical Thinking Test, Level $Z$ and English to Arabic and vice versa translation test. The data were analysed using SPSS. Results revealed that students did not use critical thinking skills sufficiently and the most frequent categories used were Deduction and Induction reasoning, followed by Semantics. The least used were Credibility and Definition. Another finding indicated that there was a statistically significant relationship between critical thinking and translation ability. Students with a higher grade in translation scored better on critical thinking test. The results could have implications for EFL teachers to improve learners' critical thinking skills as part of translation process.
\end{abstract}

Keywords: Critical Thinking, Saudi Undergraduates, English Translation, Arabic Translation, EFL Undergraduates

\section{Introduction}

In the information technology era, people have easy access to knowledge because of the integration of internet into our daily lives. This situation makes it vital for educators and students to be stimulated to think critically if they want to be able to manage the abundance of available information efficiently. Students are exposed to different viewpoints so they should be able to make Judgements about information and arguments. They should be independent thinkers. They have to be encouraged to ask questions and to analyse media reports and not to simply absorb them.

Accordingly, an urgent need for educational reform has begun to emerge where the focus of education has shifted from learning to thinking. It changes from memorization, homework, following direction and covering content into reasoning, analyzing, interpreting, making predictions, making inferences, formulating hypothesis and so on. Moon (2008) states that critical thinking development is a serious challenge in education in which students who master higher order skills are called critical thinkers.

Translation requires incorporating different skills and abilities. Kashirina (2014) divides the translation process into three stages, pre-translation source test analysis, the translation itself and selfassessment/editing. The first and third stages require critical thinking and the second stage requires creative thinking. The focus of this study is incorporating critical thinking into the curriculum and especially promoting critical thinking as an integral part of translation. 


\subsection{Statement of the Problem}

In this information age, students are exposed to different viewpoints and questionable information. So, in order to live in this world, everyone needs to rely on his critical thinking skills. Therefore, a top priority objective of every educational institution is to assess and teach higher order thinking skills. By doing so, students will learn to apply these skills to real life situations as well as to incorporate them into their educational process in which they have to reflect, analyse, solve problems and evaluate. Students will also be prepared to be critical thinkers as well as autonomous learners instead of being passive recipient of instructions from their teachers. The purpose of this study is to investigate the critical thinking level of EFL undergraduates and to investigate the need to incorporate critical thinking in raising students' translation quality.

\subsection{Objectives}

This study aims to achieve two goals:

1. To assess the critical thinking level of Saudi EFL undergraduates.

2. To investigate the significant relationship between critical thinking skills and translation ability at the category and overall levels.

Specifically, the following major research questions are addressed:

1. What is the critical thinking level of Saudi EFL undergraduates?

2. Is there any significant relationship between critical thinking skills and translation ability at the category and overall levels?

\subsection{Significance of the Study}

The easy access to information nowadays created a serious need to develop student's critical thinking. Andrews (2010) states that critical thinking is the outcome of higher education. As a result, teaching the skill of critical thinking in translation has been applied in the field of teaching English. Kashirina (2015) states that critical thinking is an integral part of translation studies and it helps in mastering translation ability effectively. Azin and Tabrizi (2016) state that teaching translation involves fostering critical thinking skills through using several cognitive and critical thinking abilities. As a result, teaching students to think critically through curriculum became popular. Thus, the focus of this study is to identify the student's ability of critical thinking and based on the results to promote critical thinking as part of the translation process.

\section{Theoretical Framework and Empirical Studies}

\subsection{The Concept of Critical Thinking}

The concept of critical thinking is not a new one; it can be traced back to Socrates when he established a new method of questioning, where people should ask deep questions, seek evidence, examine reasoning, make assumptions before accepting an idea. This method of questioning is now known as Socratic Questioning. Again, in the twentieth century, there was a call for educational reform movement, when John Dewey (1916) who is the most influential thinker on education has rejected traditional education and 
substituted it with another methodology called "hands-on" approach to learning. Where students can map their own learning and the teacher is a facilitator rather than lecturer or director. Cuban (1984) summarises Dewey's analysis of reflective thinking in five steps. They are: identify the problem, define the problem, generate hypothesis, refine the hypothesis, and test the hypothesis). Chaffee (1988) defines critical thinking as "our active, purposeful, and organised efforts to make sense of our world by carefully examining our thinking and the thinking of others in order to clarify and improve our understanding". So, critical thinking is a purposeful and organised process which results in interpretation and analysis to reach to sound judgement. Thus, the concept of critical thinking has puzzled educators as it has been confused with other kinds of thinking. As a result, dozens of definitions have been published. This situation has encouraged a body of scholars to work together for two years to develop a consensus definition of critical thinking, known as the Delphi Project. In this project they define critical thinking as purposeful, selfregulatory judgement that results in interpretation, analysis, evaluation, inference, and explanation of the evidential, conceptual, methodological, criteriological, or contextual consideration upon which that judgement is based" (Facione, 1990, p. 3). Later, Paul (1993) defines critical thinking as an intellectual process of conceptualising, applying, analysing, synthesising and evaluating information. So, Paul's notion of critical thinking as rational activity with a broad range of skills is a comprehensive one. According to Paul, there is a number of crucial intellectual standards for judging critical thinking such as clarity, accuracy, precision, relevance, depth, breadth, logic and significance. Though, to promote intellectual standards, teachers have to assess the students' thinking by the measure of the elements of reasoning such as purpose, questions, ideas, assumptions, information, inference, conclusions and consequences. Moreover, Bailin (2002) argues that critical thinking is good thinking that meets the criteria of adequacy and accuracy. On the other hand, Choy and Cheah (2009) define critical thinking as "reflection, identification and appraisal of assumptions inquiry, interpretation, and analysis and reasoning and judgement with the consideration of context" (p.198). Ennis (2011) adds that critical thinking is a process that involves thinking logically and making decisions. Finally, Kader describes the two taxonomies of critical thinking skills. They are higher order thinking skills that require judgement, analysis, and synthesis. They are reflective, sensitive to the context and self-monitored. On the other hand, the other taxonomy is lower order thinking skill which is memorization, and rote learning. They are unreflective and inapplicable.

\subsection{Teaching of Critical Thinking}

Fostering critical thinking is a core theme in the educational system nowadays, in the age of easy access to information. Students have to learn how to filter the information they receive every day. There are reasonable grounds for believing that teachers can improve the efficiency of thinking by appropriate teaching; Nickerson (1988) states "We think without being taught to do so...it does not follow from the fact that we think spontaneously, that we think as effectively, as we might... The challenge is not so much to teach thinking as it is to teach good thinking" (p.3).

Ennis (1989) provides four approaches to teaching critical thinking. The first is a general approach where critical thinking is taught as a separate programme. The second is the infusion approach. It means embedding the teaching of thinking within the curriculum. Critical thinking skills are reinforced in a variety of subject matter areas. The third approach is the immersion approach. It is promoting critical 
thinking via implicit integration in a subject matter. The last is a mixed approach. It focuses on developing critical thinking through mixing the general approach with either the infusion or the immersion approach.

\section{Empirical Studies}

There is a great deal of literature about the influence of critical thinking on many aspects of language learning and on a diverse set of academic fields such as translation, language proficiency, writing, and reading comprehension. Rashid and Hashim (2008) examined the relationship of critical thinking and language proficiency. 280 Malaysian undergraduate students participated in the study. The instruments used were the Cornell Critical Thinking Test and an English language proficiency test. Results indicated that there was significant relationship between critical thinking skills and English language proficiency.

Boloori and Naghipoor (2013) investigated the relationship between critical thinking skills and translation ability. 100 Iranian EFL undergraduates participated in the study. The instruments used were a proficiency test, a critical thinking questionnaire and a translation test. The findings showed that critical thinking correlated with students' performance in the translation test.

In the same line, Azin and Tabrizi (2016) conducted a study to explore the possible relationship between critical thinking and translation ability. The participants were 86 Iranian students from Azad University. The tools used in the study were a critical thinking questionnaire and an English to Persian translation test. The findings revealed that there was a positive significant correlation between the overall quality of the translation test and the students' critical thinking skills.

In an attempt to investigate the association of critical thinking skills, writing performance and topic familiarity, Inda (2017) conducted a study on Indonesian students from the English Department at Maulana Malik Ibrahim University. The method used in the study was an ex-post-facto design. The data were analysed by using Path analysis. The findings indicated that there is a positive relationship between the topics initiated by the students writing performance, besides, quality writing was associated with the mastery of critical thinking skills.

Similarly, Nejmaoui (2019) investigated the effect of fostering critical thinking through the teaching of argumentative writing. A quasi experiment study was conducted on 36 Moroccan EFL university students. Students took an argumentative essay pre-test and an argumentative essay post-test to measure their critical thinking skills. Illinois Critical Thinking Essay Scoring Rubric was used in the correction of the argumentative test. The findings revealed that there are differences between the experimental group and the control group. Students showed improvement in the use of critical thinking skills in argumentative writing. This assures the effectiveness in integrating critical thinking skills in writing.

\section{Methodology}

\subsection{Research Design}

A quantitative study was conducted as it is concerned with numerical data. Descriptive as well as inferential statistics were used to investigate the level of critical thinking among EFL undergraduates as well as the relationship of critical thinking with translation ability. 


\subsection{Participants}

A total of seventy-two undergraduates majoring in English participated in the study. They were enrolled in three sections of a translation course at king Khalid University. Their ages range between 19 and 23 years. They were selected non-randomly to participate in this study as they are naturally formed in a classroom.

\subsection{Instruments}

The tools used for collecting data were a critical thinking test and a translation test. Cornell Critical Thinking Test (1985), Level Z was used in this study. This test is the most commonly used one throughout the world to assess critical thinking ability. The test was developed by Ennis and Millman. It contains Fifty-two multiple-choice items and each item has three choices. This test is called "General Critical Thinking Tests" as it covers all the skills of critical thinking such as "Deduction (items1-10), Semantics (11-21), Credibility (22-25), Induction (Judging conclusions) (26-38). Induction (Planning Experiments) (39 to 42), Definition and Assumption Identification (43-46) and finally, Assumption Identification (4752). The critical thinking test was completed within a 50-minute period.

A final translation test was administered to seventy-two students. It consists of thirty multiple choice questions and two passages from Arabic into English and vice versa. The translation test scores were combined with the scores of the critical thinking test.

\section{Results}

The data were analysed by using SPSS. Descriptive statistics were used such as frequencies, means and standard deviations to provide information concerning the overall level of critical thinking as well as for the category level.

It also consisted of inferential data analysis procedures Pearson Correlation Coefficient was used to investigate the relationship between the undergraduates' critical thinking skills and their scores in the translation test. The findings from the critical thinking test and the translation test will give answers to the following research questions:

1. What is the critical thinking level of EFL undergraduates?

2. Is there any significant relationship between critical thinking skills and translation ability at the category and overall levels?

In answering the first research question, regarding the level of critical thinking of EFL undergraduates, analysis of the data using descriptive statistics is summarized in Table 1. The analysis revealed that there were some similarities and variation in the use of strategy categories among EFL students. 
Table 1: Level of Critical Thinking Skills of EFL Undergraduates - Statistics

\begin{tabular}{|c|c|c|c|c|c|c|c|c|c|}
\hline & & 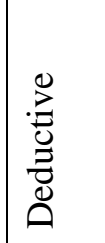 & 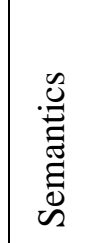 & 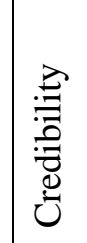 & 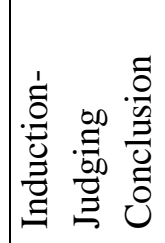 & 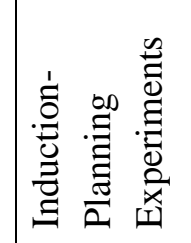 & 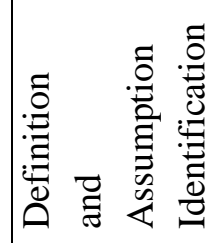 & 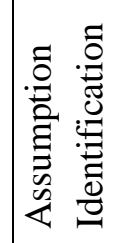 & 픙 \\
\hline & Valid & 72 & 72 & 72 & 72 & 72 & 72 & 72 & 72 \\
\hline 10 & Missing & 0 & 0 & 0 & 0 & 0 & 0 & 0 & 0 \\
\hline $\mathrm{M}$ & & 5.15 & 3.36 & 1.47 & 4.79 & 1.53 & 1.40 & 2.19 & 19.92 \\
\hline & Deviation & 2.26 & 1.60 & .90 & 1.92 & 1.06 & .97 & 1.13 & 4.02 \\
\hline & ness & 105 & 480 & .557 & .085 & 325 & .517 & .618 & -.606 \\
\hline & $\begin{array}{l}\text { tror of } \\
\text { ness }\end{array}$ & .283 & .283 & .283 & .283 & 283 & .283 & .283 & .283 \\
\hline & num & .00 & .00 & .00 & 1.00 & .00 & .00 & .00 & 8.00 \\
\hline & mum & 10.00 & 9.00 & 4.00 & 9.00 & 4.00 & 4.00 & 5.00 & 27.00 \\
\hline
\end{tabular}

Table 1 shows that EFL undergraduates reported low overall use of critical thinking skills as their mean score is 19.92 . With regard to critical thinking categories, the analysis indicated that Deduction was the most frequently used by the students followed by Induction (Judging Conclusion), next Semantics, then Assumption Identification. The least frequently used categories were Induction (Planning experiments), Credibility, Definition and Assumption Identification. The highest mark in the critical thinking test was 27 and the lowest was 8 .

Concerning the answer for the second research question regarding the relationship of critical thinking skills and translation ability, analysis of the data using inferential statistical analysis procedures is summarized in table $2 \& 3$. Pearson correlation coefficient revealed there was a significant relationship between critical thinking skills and translation test scores at two levels.

\subsection{Overall Level}

Analysis of the data obtained from the critical thinking test is illustrated in table 2. It shows the relationship between the overall critical thinking skills and the translation ability. 
Table 2: Overall Critical Thinking Skills and Translation Ability - Correlations

\begin{tabular}{|l|l|l|l|}
\hline \multicolumn{2}{|l|}{} & Scores & Final \\
\hline \multirow{4}{*}{ Scores } & Pearson Correlation & 1 & $.594 * *$ \\
\cline { 2 - 4 } & Sig. (2-tailed) & & .000 \\
\cline { 2 - 4 } & $\mathrm{N}$ & 72 & 72 \\
\hline \multirow{5}{*}{ Final } & Pearson Correlation & $.594 * *$ & 1 \\
\cline { 2 - 4 } & Sig. (2-tailed) & .000 & \\
\cline { 2 - 4 } & $\mathrm{N}$ & 72 & 72 \\
\hline **. Correlation is significant at the 0.01 level (2-tailed). \\
\hline
\end{tabular}

Table 2 shows that the obtained Pearson correlation value between critical thinking skills and translation ability is 0.594 which is significant at $\mathrm{P} \leq 0.01$. As the critical thinking skills of students' increase, their translation scores raise as well. Thus, the answer to the research question is that, there is a statistically significant correlation between critical thinking skills and translation ability. Students with higher scores in the critical thinking test scored higher in the translation test.

\subsection{At the Category Level}

In determining the relationship between critical thinking categories and translation ability of EFL undergraduate students, a summary of the analysis of the data using Pearson correlation is presented in Table 3. Results indicated that there was significant relationship between some critical thinking categories and translation test scores.

Table 3: Relationship between Critical Thinking Categories and Translation Scores - Correlations

\begin{tabular}{|c|c|c|c|c|c|c|c|c|}
\hline & & 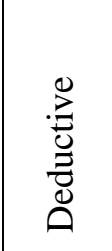 & $\begin{array}{l}\stackrel{\tilde{U}}{\Xi} \\
\stackrel{\Xi}{\Xi} \\
\stackrel{\Xi}{0} \\
\tilde{\omega}\end{array}$ & 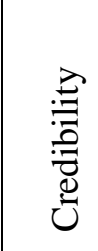 & 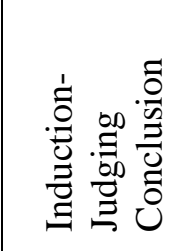 & 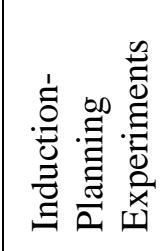 & 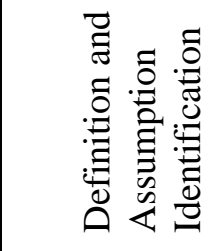 & 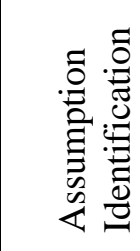 \\
\hline $\begin{array}{l}\text { Translation } \\
\text { Score }\end{array}$ & $\begin{array}{l}\text { Pearson } \\
\text { Correlation }\end{array}$ & $.532^{* *}$ & .113 & .202 & $.285^{*}$ & .101 & .014 & .103 \\
\hline & $\begin{array}{l}\text { Significanc } \\
\text { e Level }\end{array}$ & .000 & .345 & .090 & .015 & .398 & .908 & .391 \\
\hline
\end{tabular}

Table 3 shows that there is a significant relationship between students' translation scores and some categories of critical thinking such as Deductive with the observed value of Pearson $=0.532$ and Induction (Judging Conclusion) with the observed value of Pearson $=0.285$ which is significant at $p \leq 0.01$. It can be 
concluded that Deductive and Induction (Judging Conclusion) skills are related to the students' translation performance. The students' high scores on the Deductive Reasoning and Inductive (Judging Conclusions) of the critical thinking test were associated with the high scores on the translation test. On the other hand, Semantics, Credibility, Induction-Planning Experiments, Definition and Assumption Identification skills have not shown any significant relationship with translation ability. In other words, in the process of translation, successful EFL students used interpretation in order to deduce the meaning of the new terminology by applying what is presented to them, or they induce the meaning from the examples' given. These findings are convincing to the researcher as translation involves a great deal of deductive and inductive reasoning.

\section{Discussion}

The current study was carried out to assess the critical thinking level of EFL undergraduates and to find out if there was any significant correlation between the students' critical thinking and their translation ability. Descriptive statistics related to the use of critical thinking revealed that EFL undergraduates performed poorly on the critical thinking test. The overall low level of the students in critical thinking test could be attributed to a number of reasons.

It seems that critical thinking ability is not widespread. Students declared when asked by the researcher about their impression about the test that the critical thinking test was not difficult in terms of language, rather, they are unfamiliar to this type of questions and topics, and another problem is the limited time of the test.

Results of the current study also showed that students used deductive and inductive reasoning most frequently. They used linguistic aspects such as concepts, principles and theories to think critically through finding out the faulty thinking and process information (semantics). Students displayed critical thinking in all the following skills but to a limited extent. They showed that could apply critical thinking skills to reflect on justification of their assumption (Assumption Identification). They have the ability to think critically by controlling their thinking abilities. They are planners (Planning Experiments). Students have the credibility skill. They have the ability to know if the information is believable and trustworthy or not (Credibility) and finally, students were able to identify the definition for the description given (Definition).

On the other hand, results revealed that there is significant correlation between critical thinking skills and translation ability. In other words, the higher the students' score on the critical thinking test, the better their translation would be and vice versa. This finding is consistent with that of Azin and Tabrizi (2016) which states that the increase in the translation ability of the students is attributed to their critical thinking abilities. Furthermore, another finding indicated that students' deductive and inductive reasoning skills are strongly related to their translation performance; the higher they are in deductive and inductive reasoning, the better they score in translation. So, competent translators need to use different critical thinking skills. In the process of comprehending the text in the source language and producing a translation of it in the target language, students need to evaluate what makes sense and what does not from existing related information and terminology. They need to try to analyse different translations, make judgement and translate or choose the best translation (inductive). They need to apply critical thinking skills to reflect and interpret different translations and come to a reasoned conclusion (Deductive). 
There is a need for more work to be done towards enhancing the critical thinking ability of EFL university students. Teachers should be urged to improve students' critical thinking skills through instruction and practice. Teachers can use a number of teaching methods to promote critical thinking. It is recommended for teachers not to follow traditional approach in teaching. They should not consider themselves as the authority in the classroom or transmitter of information or just deliver lectures and give presentation. They should encourage student-students interaction and give more activities that stimulate students' thinking. Promoting critical thinking involves a higher level of cognitive process such as Reasoning, Deduction, Induction, and Assumption Identification. Tsui (1998) suggests that critical thinking can be improved through critical discussion, class presentations, student students' interaction and teachers' feedback. It is hoped that the results of the current study would have implication of EFL teachers in general. More work should be done towards creating an educational system that promotes critical thinking skills and develops the English language and takes up the challenges of the information era. However, further research is needed to examine if the same results apply to other undergraduates when translating, and to provide evidence on the relationship between their critical thinking skills and translation ability.

\section{Conclusion}

This study investigated the use of critical thinking of EFL learners. It also examined the relationship between critical thinking and translation ability. The results revealed poor ability of EFL undergraduates to exercise critical thinking skills. Therefore, it was essential to assess the undergraduate students' level of critical thinking skills to enable them to secure academic success and prepare them for future work. Another result demonstrated that there was significant correlation between critical thinking and translation ability. This study indicated that critical thinking skills are a good predictor of translation ability. Critical thinkers achieve more in their translation tasks. It can be concluded that more work should be done towards upgrading undergraduates' critical thinking skills for achieving better results in translation. Halpern (1999) states that critical thinking can be taught and learned. Students can receive explicit instruction on how to apply these skills to be critical thinkers. More attention should be given to developing materials and integrating activities that promote learners critical thinking skills in their translation process. A replication of this study is needed to provide more evidence on the level of critical thinking of EFL undergraduates and the relationship of critical thinking with translation ability.

\section{References}

Andrews, R. (2010). Argumentation in higher education: Improving practice through theory and research. Routledge. https://doi.org/10.1007//s10503-009-9176-5

Azin, N., \& Tabriz, H. (2016). The relationship between critical thinking ability of Iranian English translation students and their translation ability. Theory and Practice in Language Studies, 6 (3), 541-548. http://dx.doi.org//10.17507//tpls.0603.12

Bailin, S. (2002). Critical thinking and science education. Science \& Education, 11, 361-375. http://dx.doi.org/10.1023/A:1016042608621

Boloori, L., \& Naghipoot, M. (2013). The relationship between critical thinking and performance of Iranian EFL learners on translation tests. The International Research Journal, 2, 155-165.

Choy, S \& Cheah. P. (2009). Teacher perceptions of critical thinking among students and its influence on higher Education. International Journal of Teaching and Learning in Higher Education, 20 (2), 196-204.

Cuban, L. (1984). How teachers taught. Longman. 
Dewey, J. (1916). Democracy and education. Free press.

Ennis, R. (1985). Cornell critical thinking tests. Midwest publication.

Ennis, R. (1989). Critical thinking and subject specificity: Clarification and needed research. Educational Researcher, 18 (3), 4-10.

Ennis, R. (2011). Critical thinking: Reflection and perspective part 1. Inquiry: Critical Thinking across the Disciplines, 26 (1), 4-18.

Facione. P. A. (1990). The California critical thinking skills Test-College Level: Factors predicate of CT skills (Report No.2). California Academic Press.

Halpern, D. F. (1999). Teaching for critical thinking: Helping college students develop the skills and dispositions of a critical thinker. New Directions for Teaching and Learning, 80, 69-74. https://dx.doi.org/10.1002/t1.8005

Ind, R. (2017). Critical thinking, writing performance and topic familiarity of Indonesian EFL learners. Journal of Language Teaching and Research, 8 (2), 229-236. http://dx.doi.org/10.17507/j1tr.0802.04

Kadel, P. B. (2014). Role of thinking in learning. Journal of NELTA Surkhet, 4, 57-63.

Kashirina, N.A. (2014). Psychology of Translation: Critical and Creative Thinking. In M. Charron (Ed). Handbook of research on teaching methods in language translation and interpretation. AETID series. DOI: 10.4018/978-1-4666-6615-3 URL: http://www.igiglobal.com/book/handbook-research-teaching-methods-language/110032 Moon, J. (2008). Critical thinking: An exploration of theory and practice. Library of Congress.

Nickerson, R. S. (1988). On improving thinking through instruction. Review of Research in Education, $15,3-57$.

Nejmaoui, N. (2019). Improving EFL learner's critical thinking skills in argumentative writing. English Language Teaching, 12 (1), 98-109.

Paul, R. W. (1993). The logic of creative and critical thinking. American Behavioral Scientist, 37 (1), 1986-1994.

Rashid, R. A., \& Hashim, R. A. (2008). The relationship between critical thinking and language proficiency of Malaysian undergraduates, EDU-COM 2008 International Conference, Symposia and Campus Events, Australia, 19-21 November. Edith Cowan University: Research Online. http://ro.ecu.edu.au/ceducom/36

Tsui, L. (1998). Areview of research on critical thinking. ASHE Annual Meeting Paper. (ERIC Document Reproduction Service No. ED 427572). 